\title{
A piac és az állam szerepe az innovációban - Kornai János versus Joseph E. Stiglitz
}

Ebben az írásban az innováció szemszögéből vizsgálom a piac és az állam szerepét, és két kiemelkedő közgazdász, Kornai János és Joseph Stiglitz nézeteit hasonlítom össze, különös tekintettel Kornai János 2011-ben megjelent, Gondolatok a kapitalizmusról címü, illetve Joseph Stiglitz és Bruce Greenwald 2014-ben megjelent, Creating a Learning Society címü könyvére. A szerzők egészen mást gondolnak arról, hogy mi a piaci és a bürokratikus koordináció kívánatos súlya, mi a kapcsolat az innováció és a munkanélküliség között, mennyire hatékony a szabadalmi rendszer - és általában, hogy mi jellemzi az ideális, innovációt támogató gazdaságpolitikát. A mélyebb összehasonlításból azonban az is kitünik, hogy sokkal több dologban értenek egyet, mint az első pillantásra látszik. ${ }^{*}$ Journal of Economic Literature (JEL) kód: D61, H54, Z23.

\section{Bevezető}

Kevés dologban van akkora egyetértés a közgazdászok között, mint hogy az innováció kiemelt szerepet játszik a gazdasági folyamatokban, és végső soron ez határozza meg a növekedést és így az életszínvonalat. A technológiai fejlődésnek számos negatív mellékhatása is van (munkahelyek megszünése, a tudás gyors elavulása, etikai problémák, felgyorsult életmód, elidegenedés, addikciók stb.), mégis a közgazdászok általában egyértelmüen kívánatosnak és támogatandónak tekintik az innovációt. Különösen igaz ez a válság utáni időszakra, amikor az innovációösztönző gazdaságpolitikák (kockázatitőke-programok, inkubátorházak stb.) világszerte egyre nagyobb hangsúlyt kapnak.

Emellett azonban kevés dolog van, ami annyira megosztja a közgazdászokat, mint hogy mi a piac és mi az állam feladata. Újra és újra fellángol a vita, hogy a gazdaság egyes területein szükség van-e egyáltalán állami beavatkozásra, és ha igen, akkor mi

* A kutatást az MTA Bolyai János ösztöndíja támogatta. A tanulmány eredeti változata a Simonovits András 70. születésnapja alkalmából készült kötetben jelent meg (Király-Gál [2016] 351-370. o.).

Berlinger Edina a Budapesti Corvinus Egyetem docense (e-mail: edina.berlinger@uni-corvinus.hu). A kézirat első változata 2016. november 11-én érkezett szerkesztőségünkbe.

DOI: http://dx.doi.org/10.18414/KSZ.2017.4.377 
annak a célszerü formája. A vitákban általában szétválaszthatatlanul keverednek a hatékonysági (közgazdasági) és a világnézeti (politikai) érvek.

Ebben az írásban kifejezetten az innováció szemszögéből vizsgálom a piac és az állam szerepét, és két kiemelkedő közgazdász, Kornai János és Joseph Stiglitz nézeteit hasonlítom össze, különös tekintettel Kornai János 2011-ben megjelent, Gondolatok a kapitalizmusról címü, illetve Joseph Stiglitz és Bruce Greenwald 2014-ben megjelent, Creating a Learning Society címü könyvére (Kornai [2011] és Stiglitz-Greenwald [2014]). ${ }^{1}$ Számos oka van ennek a szükítésnek.

- A RepEc/CitEc adatbázis szerint Kornai János és Joseph Stiglitz egyaránt benne van a világ közgazdászainak legfelső 2 százalékában. ${ }^{2}$

- Kornai János és Joseph Stiglitz mindketten kétségkívül nagy hatást gyakoroltak a közgazdaságtan fejlődésére. Kornai János komoly kritikát fogalmazott meg a szocialista tervgazdálkodásról, összehasonlította a szocialista és a kapitalista rendszert, és mindig a kapitalista piacgazdaság elkötelezett híveként nyilvánult meg, bár feltárta a kapitalizmus (és a fóáramlatú piacmodellek) számos hiányosságát is. Joseph Stiglitz másik irányból közelítve föként a piaci kudarcokra (különösen az aszimmetrikus információkra és az externáliákra) helyezte a hangsúlyt, és ezen az alapon nemzeti stratégiát és állami beavatkozást sürgetett a legkülönbözőbb területeken, például a nemzetközi kereskedelemben, a vállalatirányításban, a pénzügyi válságok és a szegénység kezelésében.

- A hazai politikai, közéleti vitákban is gyakran felmerülnek Kornai János és Joseph Stiglitz gondolatai, bár sokszor igencsak leegyszerüsített és egydimenziós formában. Akik kisebb államot szeretnének, és abban hisznek, hogy „a piac mindent megold”, általában Kornaira hivatkoznak; akik ezzel szemben a túlméretezett, a megszokott feladatkörein messze túllépő, mindent centralizálni kívánó, „,unortodox” eszközöket felhasználó államot akarják védeni, vagy egyszerüen csak a foáramlatú közgazdaságtannal kapcsolatos csalódottságuknak akarnak hangot adni, azok előszeretettel hivatkoznak Stiglitzre (valószínü, hogy az ellentábor ostorozására használatos „,neoliberális” jelzőt is töle kölcsönözték). Meg kell azonban jegyezni, hogy Kornai sohasem állította, hogy a piac önmagában tökéletesen müködik, és nincs szükség állami beavatkozásra; mint ahogy Stiglitz sem vonta kétségbe soha a piacgazdaság alapvető erényeit és a piaci koordináció elsődlegességét. Alaposabb szemlélődés után kiderül, hogy nézeteikben jóval több a hasonlóság, mint a különbözőség. Mindketten a piac és az állam együttműködésében hisznek, mindkettőjükre igaz az, amit Kornai írt saját magáról: „fél lábbal benne vagyok a fóáramlatban, fél lábbal pedig kiléptem belőle" (Kornai [2011] 15. o.); mindketten elöszeretettel alkalmazzák a szigorú matematikai formalizmust, ám tisztában vannak annak korlátaival, és szükség esetén szívesen túllépnek azon.

- Az is egyértelmü azonban, hogy Kornai és Stiglitz sok tekintetben egészen eltérö szempontokat hangsúlyoznak, és így lényegesen eltérö következtetésekre jutnak.

\footnotetext{
${ }^{1}$ Stiglitz és Greenwald könyve nemrég jelent meg magyarul A tanuló társadalom megteremtése címmel a Napvilág Kiadó gondozásában.

${ }^{2}$ Figyelemre méltó, hogy ugyanezen lista alapján (https://ideas.repec.org/top/top.person.all.html letöltve 2016. szeptember 17.) a magyar közgazdászok közül Kornai Jánoson kívül csak Darvas Zsolt, Köszegi Botond, Simonovits András, Szeidl Ádám és Valentinyi Ákos van benne a top 8 százalékban.
} 
A véleménykülönbségek jelentős része valószínüleg az eltérő életpályának és környezeti inspirációknak köszönhetö.

Kornai kezdetben egyfajta ideológiai elszigeteltségben, személyesen tapasztalta meg a túlzott központosítás minden hátrányát, a szabadságjogok súlyos korlátozását, a hiánygazdaságot, a technológiai lemaradást és a pangást; majd végigélte a rendszerváltás felszabadító élményét, és később megfigyelte, megértette, de személyesen nem osztotta az ezzel kapcsolatos elégedetlenséget.

Stiglitz ezzel szemben beleszületett a kapitalista rendszerbe, a legjobb amerikai egyetemeken tanult, és olyan nagynevü közgazdászok voltak a mesterei, mint Kenneth Arrow, Paul Samuelson és Robert Solow. A Világbank vezető közgazdászaként azonban egészen közelröl szembesült a fejlődő országok számos problémájával, amelyeket sok esetben súlyosbított az IMF által elóírt, drasztikus piaci liberalizáció. Még ennek a két, jelentősen eltérö életpályának is van számos közös pontja: mindketten neves amerikai egyetemeken tanítottak/tanítanak, illetve tanácsadóként részt vettek/vesznek a gyakorlati gazdaságpolitika kialakításában. További érdekesség, hogy egy ideig mindketten betöltötték a Nemzetközi Közgazdasági Társaság (International Economic Association, IEA) elnöki tisztét. ${ }^{3}$

Ebben a cikkben szeretném bemutatni, hogy az első látásra homlokegyenest ellentétesnek tűnő következtetések valójában kiegészítik egymást. Először a két szerző véleményének összevetésével a piac és az innováció kapcsolatát elemezem, majd az állami beavatkozással foglalkozom az innováció szemszögéből, végül kísérletet teszek egyfajta kritikai összegzésre.

\section{Piac és innováció}

A Kornai [2011] kötet első - Innováció és dinamizmus címü - tanulmánya kiemelten a kapitalista rendszer és az innováció kapcsolatáról szól. Fő tézise, hogy a kapitalista rendszer egyik legfontosabb előnye a szocialista rendszerrel szemben az, hogy nagyon erős a hajlama az innovációra. ${ }^{4}$ Ennek okait elemezve kiemeli, hogy ez főként annak köszönhető, hogy a kapitalista rendszerben a kezdeményezés decentralizált, a jutalom siker esetén óriási, a verseny erős, széles körü lehetőség van a kísérletezésre, és a fejlett tőkepiacoknak köszönhetően könnyebb a finanszírozás.

Bizonyítékképpen a Kornai [2011] tanulmányának 1. táblázatában számos fontos, a hétköznapokat jobbá tevő, forradalmi újítás szerepel, és a szerző azt is feltüntette, hogy az adott innováció mikor, melyik országban és melyik cégnél jelent meg először (31-34. o.). Figyelemre méltó, hogy a 89 tételből álló felsorolásban nem szerepel egyetlen olyan innováció sem, amely nem kapitalista országból származik. Ugyanígy a 2., 3. és 4. táblázat, valamint az 1. ábra meggyőzően mutatja, hogy a szocialista országok nemcsak

\footnotetext{
${ }^{3}$ Kornai 2002-ben, Stiglitz pedig 2011-2014 között volt az IEA elnöke.

${ }^{4}$ Kornai a legfontosabb előnynek azt tekinti, hogy a kapitalizmus teremti meg a demokrácia lehetőségét: „A demokrácia nem működhet kapitalizmus nélkül.” (Kornai [2016] 1094. o.)
} 
a találmányok, de azok átvétele, elterjesztése tekintetében is látványosan lemaradtak a kapitalisták mögött (32-38. o.). Pedig a keleti blokk országaiban is születtek nagyszerü találmányok, de a bürokratikus centralizáció nem támogatta, sőt kifejezetten gátolta a fejlesztést és a gyártást (az elszalasztott lehetöségekre példaként említi Kornai a félvezetőket, a minikomputert, a Rubik-kockát és a floppy disket), majd összeveti ezeket a kudarctörténeteket a rendszerváltás utáni látványos sikerekkel (például a Skype szoftvere, Graphisoft, elveszett adatok merevlemezröl való visszaszerzése).

Mindezek alapján Kornai felrója a közgazdászoknak és a politikusoknak, hogy elmulasztották hangsúlyozni a rendszerváltozásnak az innovációkra és így az életszínvonalra gyakorolt, rendkívül pozitív hatását.

„A közgazdaságtan fóáramlatát gyakran vádolják azzal, hogy a kapitalizmus kedvező tulajdonságait reklámozza. Ha ez a szándéka, akkor meglehetősen gyenge munkát végez..., mert meg sem említi a rendszer fö erényei közül az egyik legfontosabbat, az innovációra irányuló, viharos erejü, megállíthatatlan hajlamot." (Kornai [2011] 63. o.)

Kornai [2011] részletesen bemutatja, hogy a rendszerváltás szabad teret engedett a schumpeteri értelemben vett, úgynevezett teremtő rombolásnak, melynek a „rombolás” részét (munkahelyek megszünése, tudás elavulása, növekvő bizonytalanság, növekvő egyenlőtlenség stb.) az emberek egyértelmüen a piacgazdasághoz kötötték, miközben a „teremtést” (új technológiák megjelenése, növekvő életszínvonal, nagyobb vállalkozói szabadság stb.) már nem kapcsolták össze közvetlenül a rendszerváltozással, és különösen az innovációt hajlamosak független külső adottságnak tekinteni. Ez a „tulajdonítási hiba” azért is feltűnő, mert a keleti blokk országaiban rendre magasabbra értékelik a technológiai fejlődés jótékony hatását, mint a nyugati országokban (lásd az említett tanulmány 9. és 10. táblázatait a 60. és a 61. oldalon).

Stiglitz-Greenwald [2014] teljes mértékben egyetért Kornaival abban, hogy a technológiai fejlődés alapvetően meghatározza az életszínvonalat, és mind társadalmi, mind gazdasági szempontból kiemelten lényeges kérdés, hogy az innovációs folyamat a lehetö legjobban müködjön. Fontos elméleti kiindulópont azonban számukra Arrow-Debreu [1979/1954] modellje, amelyben a szerzők meghatározták azokat a szigorú feltételeket, amelyek ahhoz szükségesek, hogy a piaci mechanizmusok Pareto-optimális állapotot hozzanak létre, és amelyek nyilvánvalóan nem teljesülnek a valóságban. Kornaival közös irodalmi elözménynek tekinthető Solow [1957] is, amely kimutatta, hogy az országok termelésének növekedési ütemét alapvetően nem a termelési tényezök (munka és tőke) mennyisége, hanem a technológiai fejlődés magyarázza.

Mindezek mellett Stiglitzéknél is kiemelt figyelmet kap Schumpeter [1980/1912], amely a kapitalizmust mint a folyamatos teremtő rombolás evolúciós folyamatát írja le, ahol a vállalkozó játssza a föszerepet, hiszen ő a haladás szempontjából legfontosabb képességek hordozója. Kiemelendő, hogy a schumpeteri modellben az innováció fö ösztönzője a szabadalom (patent), amelynek az a lényegi funkciója, hogy időszakos monopolhelyzetet biztosítson a sikeres feltalálónak/újítónak. A szabadalom tehát, ha csak átmenetileg is, de egyértelmüen korlátozza a piaci versenyt. Ezt a feszültséget Schumpeter úgy oldja fel, hogy a „piacon” folyó versenyt véleménye szerint felváltja a „piacért”, azaz a domináns pozícióért folyó verseny, ami a statikus 
hatékonyságveszteségért cserébe biztosítja a dinamikus hatékonyságot (ezt az állítást azonban Schumpeter sosem bizonyította formálisan). Miközben Kornai teljes mértékben elfogadja ezt az érvelést, a Stiglitz-Greenwald páros szerint Schumpeter túlzottan optimista volt a monopóliumok megítélésében; modelljeikben ugyanis levezetik, hogy a monopóliumoknak minden érdekeltségük és eszközük megvan ahhoz, hogy domináns pozíciójukat folyamatosan fenntartsák (például az innovációk elrettentésével, valamint a szabadalmi játszmákkal), és ilyen körülmények között az innováció ösztönzése sokkal kevésbé hatékony, mint azt Schumpeter gondolta.

Stiglitzék megközelítésében az az újdonság, hogy a cselekvés közbeni tanulást (learning by doing) helyezik a középpontba, amelyet Arrow [1979/1962] fogalmazott meg először. Ennek lényege, hogy a cselekvés (termelés) lényeges mellékhatása a tanulás (innováció), hiszen miközben termelünk, folyamatosan tökéletesítjük az eszközöket és az eljárásokat. ${ }^{5}$ Ráadásul, mivel az így létrejövő új tudás valamilyen mértékben mindig tovagyürüzik, más gazdasági szereplők is élvezhetik pozitív hatásait. A modern gazdaságokban a cselekvés közbeni tanulásban tehát jelentős pozitív externális hatás érvényesül, amit azonban a magánszereplök maguktól sajnos nem vesznek figyelembe beruházási döntéseikben. Ebből következik, hogy a társadalmi optimumhoz képest túl kevés (és túl kicsi) projekt valósul meg, azaz túl alacsony lesz a termelés szintje, emiatt túl kevés lesz a tanulás és az innováció is, s így végeredményben a gazdasági növekedés sem lesz optimális. Vagyis egyfajta piackudarccal szembesülünk.

Figyelemre méltó, hogy Stiglitz-Greenwald [2014] is kitér a rendszerváltozás elemzésére, lásd könyvük második fejezetét. A szerzőpáros is megállapítja, hogy a rendszerváltozás környékén a balti és a kelet-közép-európai, vagyis az úgynevezett központosított országok mind a GDP, mind a várható élettartam tekintetében messze le voltak maradva a nyugati, úgynevezett nem központosított országoktól (annak ellenére, hogy a második világháború után például Csehszlovákia fejlettebb volt Ausztriánál, és Lengyelország fejlettebb volt Spanyolországnál). Ezt a tényt azonban a szerzők - Kornaitól eltérően - föként azzal magyarázzák, hogy a volt szocialista országok túl nagy súlyt helyeztek a hagyományos termelési tényezők, tehát a tőke és a munkaerő felhalmozására, ám kevés figyelmet fordítottak a termelés közbeni tanulásra. Úgy vélik, ezek a különbségek jóval nagyobbak voltak annál, mint amit „egyszerüen” a rossz ösztönzőkkel és/vagy a nem hatékony forrásallokációval lehetett volna magyarázni. Ezt a véleményüket igyekeznek azzal is alátámasztani, hogy a rendszerváltozás után az egyes országok termelékenységében még sokáig nagyon nagy eltérések maradtak fenn (olyan eltérések, amelyek nem magyarázhatók a tényezőellátottsággal), vagyis a piacgazdaságra való áttérésnek sok esetben nem mutatkoztak meg automatikusan a pozitív hatásai. Például hiába tértek át a piacgazdaságra, sok kelet-európai ország és a balti országok kevésbé voltak sikeresek, mint mondjuk Kína, India, Vietnam és Dél-Korea, ahol az elmúlt évtizedekben tapasztalható látványos termelékenységnövekedés Stiglitz és Greenwald szerint egyértelmüen a jól irányzott, tervszerü állami szerepvállalásnak köszönhető. Vegyük észre, hogy ezzel a megállapítással a

\footnotetext{
${ }^{5}$ A tudás növekedése Arrow [1979/1962]-ben a beruházással, míg Stiglitz-Greenwald [2014]-ben a megvalósuló projekt méretével arányos.
} 
szerzők lényegében tagadják - vagy legalábbis jelentősen kisebbítik - a piac és a rendszerváltozás jelentőségét az innováció szempontjából.

Érdekes módon tehát Stiglitz-Greenwald [2014] pontosan azért kárhoztatja a piaci mechanizmusokat, amiért Kornai a bürokratikus koordinációt: nevezetesen, hogy nem engedi kellőképpen kibontakoztatni az innovációkban rejlö lehetőségeket. StiglitzGreenwald [2014] éppolyan élesen kritizálja a fóáramlatú közgazdaságtant azért, mert nem számolnak a fent említett tanulási externáliával, mint Kornai János azért, mert nem hangsúlyozzák eléggé a piaci mechanizmusok kulcsszerepét az innovációban.

„Az a tény, hogy a piacok önmagukban nem hatékonyak, ha az innováció endogén, felvet egy fontos kérdést...: mi legyen a szakpolitika szerepe a gazdasági hatékonyság előmozdításában? A korlátozásoktól mentes piacok híveinek a válasza e kérdésre gyakran az, hogy magasztalják a piac képességét az innovációra. Ám figyelemreméltóan csekély az olyan szisztematikus kutatás, amely azt vizsgálja, hogy vajon a piacok képesek-e az innováció optimális szintjét és formáit előállítani." (Stiglitz-Greenwald [2014] 3. o.)

Stiglitz-Greenwald [2014] 5. és 6. fejezete részletesen megvizsgálja a különböző piacszerkezetek (tökéletes versenyzői, oligopolisztikus, monopolisztikus) hatását az innovációra, feltételezve a tudás továbbgyürüzésének különböző fokozatait (teljes, részleges, egyáltalán nem tovagyürűző). A monopóliumnak kettős hatása van: egyrészt érvényesül a klasszikus összefüggés, hogy a monopólium kevesebbet termel, mint a versenyzö vállalatok összessége (ami csökkenti a tanulást), másrészt azonban ösztönzést teremt a szabadalom megszerzésére (ami fokozza az innovációt). Végeredményül azt kapjuk, hogy a néhány nagyvállalat által dominált oligopolisztikus-monopolisztikus piacokon több az innováció, mint a sok kis céggel jellemezhető, erősen versenyzői piacokon. ${ }^{6}$ Ez az eredmény összhangban van azzal a schumpeteri gondolattal, hogy nem a piacon, hanem a piacért folyik a verseny. A kérdés azonban ennél sokkal bonyolultabb, mert a hatás kétirányú, azaz nemcsak a piacszerkezet hat az innovációra, hanem az innovációk is - a szabadalmak által biztosított monopóliumok révén - visszahatnak a piacszerkezetre. Stiglitz és Greenwald változatos modellek segítségével elemezte ezt a bonyolult dinamikus összefüggést, és megállapította, hogy állami beavatkozás nélkül a piacszerkezet a hosszú távú, „bebetonozott” monopólium felé tart, és egyáltalán semmi sem biztosítja, hogy az eredmény Pareto-optimális legyen, akár csak gyenge értelemben (azaz, hogy ne lehetne állami beavatkozással javítani a helyzeten). Ráadásul nemcsak az a baj, hogy a piaci egyensúlyban túl kevés az innováció, hanem az is, hogy az innovációk egy része rossz irányú; például túl sok energiát pazarolnak a már meglévő szabadalmak kijátszására, a piaci erőfölény megtartására, a szennyező technológiákra vagy éppen a munkahelyeket kiváltó újításokra. ${ }^{7}$

A szerzőpáros arra is felhívja a figyelmet, hogy válság idején általában fokozottan elötérbe kerülnek a munkaerő-megtakarításra irányuló innovációk, ami pont a legrosszabbkor fokozza a társadalmi feszültségeket. Elvben ugyanis az innovációk irányulhatnának

\footnotetext{
${ }^{6}$ Az már nem biztos azonban, hogy a jólét is növekszik ennek hatására, ez a paraméterértékek függvénye.

Stiglitz és Greenwald a pénzügyi innovációk jelentős részét (például a strukturált derivatív termékeket) is a tökéletesen értelmetlen, sőt a társadalom számára kifejezetten káros találmányok közé sorolja.
} 
tőkemegtakarításra is, például egy drága gép olcsóbb technológiával való kiváltására. Tiszta piaci mechanizmusok esetén azonban erre kevés az ösztönző, mivel a munkanélküliség is egyfajta (negatív) externália, azaz nem közvetlenül a döntést meghozó magánszereplőket, hanem a szélesebb társadalmat érinti hátrányosan.

Kornai [2011] szerint a munkanélküliség (alacsony foglalkoztatás) a kapitalizmus rendszerspecifikus jellemzője ${ }^{8}$ (amely lényegében a magántulajdon, a kemény költségvetési korlát és a piaci árak és bérek következménye), és minél erösebben érvényesülnek a kapitalista rendszer jó tulajdonságai (innováció és növekedés), annál magasabb a munkanélküliség. Kornai [2011] szerint: „Lehet - és kell is - olyan makrogazdaságpolitikát folytatni és olyan intézményeket teremteni, amelyek csökkentik és elviselhetőbbé teszik a munkanélküliséget" (127. o.), de teljes foglalkoztatást ígérni felelőtlenség - legalábbis a kapitalista rendszerben.

Vegyük észre, hogy a munkanélküliséget mindkét közgazdász közvetlen kapcsolatba hozza a piaci mechanizmusokkal és az innovációval, és mindketten nagyon súlyos problémának tekintik, amelyet az államnak valamilyen módon enyhítenie kell. A vélemények inkább abban különböznek, hogy mi az oka a munkanélküliségnek, és föleg, hogy mit tehet az állam ezen a területen. Kornai inkább a szociálpolitikai eszközöket hangsúlyozza annak érdekében, hogy elviselhetőbb legyen ez a kényszerü állapot; ezzel szemben Stiglitzék olyan állami gazdaságpolitikát javasolnak, amely a termelés fokozásával és/vagy a termelési szerkezet megváltoztatásával növeli a foglalkoztatást.

Stiglitz és Greenwald kiterjesztette a klasszikus közgazdasági modelleket a cselekvés közbeni tanulással, és részletekbe menő matematikai formalizmussal igazolta, hogy a termelés növelésére irányuló állami beavatkozás jelentős értéket teremthet az egész társadalom számára. Más szóval, az állami beavatkozás hosszú távon érvényesülő dinamikus hasznai általában messze meghaladják annak költségeit.

A következőkben az állami beavatkozás lehetséges formáiról lesz szó részletesen.

\section{Állam és innováció}

Kornai elismeri, hogy számos olyan nem schumpeteri mechanizmus létezik, amely elömozdítja az innovációt, például a hadiipar (email, teflon, pillanatragasztó stb.), a kormány egyéb szektorai (egészségügyi kutatások stb.), illetve egyéb polgári, nonprofit, partneri szerveződések (sms, Linux operációs rendszer stb.) kezdeményezései. Véleménye szerint azonban ezek jelentősége eltörpül a piaci hajtóerőkhöz képest: „Elismerve minden más magyarázó változó fontosságát, fenntartom az álláspontot, hogy a rendszerspecifikus hatás igen erös." (Kornai [2011] 46. o.) Ebből következik, hogy Kornai szerint az állam azzal tesz a legtöbbet az innovációkért, ha biztosítja a piac megfelelő müködését a keretfeltételek megteremtésével (például magántulajdon védelmével, kemény költségvetési korláttal, versenyszabályozással stb.).

Stiglitzék azonban amellett érvelnek, hogy az állam nem elégedhet meg azzal, hogy létrehozza a támogató üzleti környezetet, hanem ezen túlmenően aktívan be kell

\footnotetext{
${ }^{8}$ A kapitalizmus másik rendszerspecifikus jellemzője Kornai [2011] szerint a túlkínálatos árupiac.
} 
avatkoznia az innováció érdekében. Véleményük szerint „a tanuló társadalom létrehozását a gazdaságpolitika egyik legfontosabb célkitüzésévé kell avatni" (StiglitzGreenwald [2014] 6. o.). Ezen azt értik, hogy az államnak támogatnia kell a termelést (!) azokon a területeken, ahol 1 . feltételezhetöen legeröteljesebb a termelés közbeni tanulás, és/vagy 2. ahonnan a technológiai tudás leginkább tovagyürüzik más szektorok irányába. Különösen igaz ez a fejlődő országok esetében, ahol a fö cél a tudásbeli szakadék szükítése, vagyis a fejlett technológiák átvétele és elterjesztése.

Stiglitz-Greenwald [2014] egyértelmüen abból indul ki, hogy az innováció motorjának nem a dinamikus kis- és középvállalatok (például startup cégek), hanem a földrajzilag koncentrált, ipari nagyvállalatok tekinthetők, ${ }^{9}$ mivel véleményük szerint mind az innováció, mind a tovagyürüző hatás itt a legnagyobb. A következőkben röviden összefoglaljuk gazdaságpolitikai ajánlásaik lényegét és a mögöttük húzódó érveket.

\section{Ipar-és kereskedelempolitika}

A fejlődő országoknak nem szabad leragadniuk az aktuálisan fennálló komparatív előnyöknél, hanem úgy kell alakítaniuk gazdaságuk szerkezetét, hogy új, nemzetközileg is versenyképes, tanuló iparágak jöjjenek létre. Követendő példaként említik Dél-Koreát, melynek pár évtizeddel ezelőtt csak a rizstermelésben volt komparatív előnye, de a tudatos állami gazdaságpolitikának köszönhetően jelentős fejlődést ért el az elektrotechnika területén, és így ma már ezen a területen van komparatív elönye; és mindeközben az egész gazdaság magasabb növekedési pályára állt.

A fiatal iparág (infant industry) melletti hagyományos érvelés szerint az államnak támogatnia kell a legígéretesebb iparágakat, illetve vállalatokat. Ezzel azonban az a probléma, hogy az állam általában nem képes jól kiválasztani a nyerteseket. Ezért Stiglitz-Greenwald [2014] inkább azt javasolja, hogy a fiatal gazdaságra (infant economy) vonatkozó érvelés szellemében az egész gazdaságot (jellemzően az ipart) támogassa az állam, méghozzá széles körü, általánosan hozzáférhető, azaz keretjelleggel müködtetett eszközökkel, konkrétan 1. vámakadályokkal (importkorlátozásokkal), 2. devizapiaci intervenciókkal (a hazai valuta gyengítésével) és 3. normatív exporttámogatásokkal (az exporttevékenység volumenéhez kötődő, automatikusan lehívható állami támogatásokkal/adókedvezményekkel). Emellett elismerik, hogy a külföldi müködőtőke-befektetések is fokozhatják a tanulást, de ennek sikere a megvalósítás részleteiben rejlik (például mennyire sikerül előírni és érvényesíteni a hazai beszállítói hányadra vagy a foglalkoztatásra vonatkozó követelményeket).

A szerzők szerint - mivel a nemzetközi kereskedelmi és beruházásvédelmi egyezmények általában tiltják a vámokat, a hazai vállalatok közvetlen támogatását és a müködő tőke korlátozását - a felsorolt eszközök közül a legkézenfekvőbb és legrugalmasabb eszköz az árfolyam menedzselése. Matematikai modellek segítségével azt

\footnotetext{
${ }^{9} \mathrm{Az}$ „ipar” kifejezést a köznyelvtől eltérően használja a szerzőpáros: beleérti a fejlett szolgáltatóipart, a gépesített, nagyüzemi mezőgazdaságot, de kizárja belőle például a kézművesipart.
} 
is megmutatták, hogy az iparvédelmet érdemes lehet folyamatosan fenntartani, még akkor is, ha a gazdaság örökre a felzárkózás szakaszában marad, mert a tanulásból fakadó hosszú távú előnyök meghaladják az aktuális komparatív előnyök negligálásából adódó átmeneti hátrányokat.

\section{Pénzügypolitika}

A szerzők szerint a pénz- és tőkepiacok liberalizálásának számos negatív hatása van a tanulásra. Egyrészt olyan gazdasági szerkezet létrejöttét erösíthetik (például a mezögazdaság vagy a nyersanyag-kitermelés túlfinanszírozásával), ami nem feltétlenül kedvez a tanulásnak és az innovációknak.

Másrészt szerintük az ilyen intézkedések akadályozzák magának a pénzügyi szektornak a tanulását. Amikor egy ország tőkét importál, akkor valójában tőkeszolgáltatásokat importál. Innentől pedig ugyanaz az érvelés érvényes, mint amit az egyéb áruk és szolgáltatások importja kapcsán az elözőkben láthattunk.

Harmadrészt, egyáltalán nem elhanyagolható szempont az, hogy a pénzügyi liberalizáció növeli a makrogazdasági volatilitást, például azért, mert a külföldi tőke tulajdonosainak kevesebb információja van a helyi gazdaságról, ezért hajlamosak túlreagálni egy-egy jelzésként értelmezett hírt. A forrótőke hektikus országhatárokon keresztüli áramlása fokozza a bizonytalanságot, ami kedvezőtlenül érinti az egyébként is bizonytalan megtérülésü $\mathrm{K}+\mathrm{F}$-beruházásokat.

Érdemes megjegyezni, hogy a szerzők ugyanezen logika szerint levezetik azt is, hogy nemcsak az áruk és a tőke, de a munkaerő mobilitását is érdemes korlátozni a tanuló társadalom létrehozása érdekében.

\section{Szellemi tulajdonjogok}

A fejlett országokban, különösen az Egyesült Államokban, az innováció legföbb ösztönzöje a szellemi tulajdonjogok (intellectual property rights, IPR) védelme, hiszen a szabadalom megszerzése meghatározott ideig és feltételek mellett monopolhelyzetet biztosít a tulajdonosának az adott áru/szolgáltatás piacán. A feltaláló/újító jutalma tehát az, hogy kisajátíthatja a fogyasztói többlet egy részét, és ennek a mértéke attól függ, hogy mennyire képes ezzel a lehetőséggel (vissza)élni.

Ennek a gyakorlatnak számos negatív következménye van. Például életmentő gyógyszerek esetén, ha az adott országban nincs mindenkire kiterjedö, államilag finanszírozott egészségügyi alapellátás, vagy az adott országnak nagyon korlátozottak az egészségügyre költhető forrásai, akkor a gyógyszercégeknek való kiszolgáltatottság társadalmi költsége nagyon magas lehet. A szellemi tulajdonjogok védői erre azt mondják, hogy ezekért a statikus költségekért messze kárpótolnak a hosszú távú dinamikus hozamok, amelyek a szabadalmak innovációösztönző hatásából adódnak.

A szerzők szerint azonban ezek a dinamikus előnyök is erősen kétségesek. Egyáltalán nem biztos ugyanis, hogy a szellemi tulajdonjogok szigorúbb rendszereiben 
nagyobb az innováció mértéke. Hiszen a monopolista számos technikát bevethet annak érdekében, hogy bebetonozza a pozícióját (a legjobb példa erre a Microsoft), és ezzel tartósan elrettentse a versenytársakat a kutatástól.

Továbbá azt is tudjuk, hogy a monopólium kevesebbet termel, így a termelés közbeni tanulás hatása is kisebb lesz. Mivel az innovációk egymásra épülnek, a titkolózás gátolja az újabb innovációkat, még akkor is, ha a szabadalom feltételéül szabják az alapvető összefüggések közzétételét (a mi alól a cégek „kreatív” módokon igyekeznek kibújni).

Problémát okoz az is, hogy a szabadalmak maguk is a korábbi tudásra épülnek, és mivel nagyon nehéz pontosan megkülönböztetni a régi és az új tudást, sok esetben a szabadalom tulajdonosa érdemtelenül sajátítja ki a közös tudás egy részét, ami korlátozza a többieket az innovációban. A szabadalmak erősítik a titkolózás kultúráját, ami ha elterjed például az egyetemeken is (és sajnos vannak erre utaló tendenciák), akkor az alapvetően aláássa a tudásfelhalmozás és -átadás intézményrendszerét.

Ugyanígy problémát jelent az is, hogy nagyon nehéz definiálni a szabadalmak terjedelmét és újdonságtartalmát. Nem csoda, hogy egész iparág növekedett ki a szabadalmi viták rendezésére (illetve sok esetben gerjesztésére). Egyes becslések szerint az Egyesült Államokban többet költenek szabadalmi perekre, mint állami kutatásokra. A pereskedés miatti bizonytalanság komolyan akadályozza a tanuló beruházásokat. Az úgynevezett szabadalmi bozótok (patent thicket), vagyis a kibogozhatatlanul összefüggő találmányok szövevénye miatt a feltaláló vagy a felhasználó sohasem tudhatja, hogy tevékenységével nem sért-e éppen valamilyen bejegyzett találmányt. Ez egy olyan ingoványos terület, amit előszeretettel kihasználnak a szabadalmi trollok és útonállók (holdups), egyesek ugyanis fötevékenységként üzik, hogy olcsón felvásárolnak érdektelennek tűnő szabadalmakat, majd arra várnak, hogy valaki a közelükbe tévedjen, és akkor azonnal lecsapnak rá a teljes jogi arzenál felhasználásával.

Adódik a következtetés, hogy a szellemi tulajdonjogok erős rendszerében az innovációk jelentős része nem a társadalmi haladást szolgálja, hanem a monopolhatalom fenntartását, a létező szabadalmak kijátszását vagy éppen a közös tudás kisajátítását. Ilyen helyzetben felerősödnek az értelmetlen szabadalmi hajszák, amire a legjobb példa az, amikor az emberi genom részletes feltérképezésére irányuló, nagy nemzetközi összefogásban megvalósuló, államok által finanszírozott, szisztematikus kutatásnak elébe szaladt a Myriad nevü cég, és felhasználva a rendelkezésre álló előzetes eredményeket (a közös tudást), egy kicsivel hamarabb eljutott a mellrák génjének megismeréséhez, és így alkalma volt megszerezni a szabadalmat, amivel hosszú időre biztosította magának a magas megtérülést.

A szellemi tulajdonjogok túlhajszolását illető eröteljes kritikák ellenére a szerzök nem azt javasolják, hogy szünjön meg a szabadalmi rendszer, hanem azt, hogy az állam törekedjen a szellemi tulajdonjogok reformjára, amelynek során kapjon nagyobb hangsúlyt a közérdek a magánérdekkel szemben, illetve törekedjen egy egészséges nemzeti innovációs rendszer kialakítására, amelyben a szabadalmak mellett kapjanak nagyobb hangsúlyt a pályadíjak, az állam által finanszírozott kutatások és a nyílt forráskód. 


\section{Egyéb eszközök}

A fenti eszközök mellett Stiglitz-Greenwald [2014] röviden megemlíti még az oktatási és a müszaki-fejlesztési politikát, a vállalatirányítási rendszereket, a csődszabályozást stb., amelyeket szintén ebben a szemléletben kellene újragondolni és megreformálni. A szerzők külön hangsúlyozzák a szociális védőháló és a munkavédelem fontosságát is, mondván, hogy a szorongás gátolja a tanulást.

Egy egész fejezet szól a társadalmi vélekedésekről (beliefs) és változásuk modellezéséről. Ezek a vélekedések ugyanis alapvetően meghatározzák a tanulással, a vállalkozással és az innovációval szembeni hozzáállásunkat. Ráadásul a vélekedések nemcsak a viselkedésünket, hanem a valóságérzékelésünket is befolyásolják, és így hosszabb távon sokszor önbeteljesítök. A szerzők úgy vélik, hogy a kormányzati politika képes hatni ezekre a vélekedésrendszerekre, és segíthet abban, hogy a társadalom innovatívabbá váljon.

\section{Vélemények, vitatott kérdések}

A következőkben röviden ismertetjük Kenneth Arrow, Robert Solow és Philippe Aghion legfontosabb kritikai észrevételeit a szerzőpáros mondanivalójával kapcsolatban, amelyek rendhagyó módon a Stiglitz-Greenwald [2014] kötet végén kaptak helyet. A neves közgazdászok kritikai észrevételeihez hozzáfüzöm a saját gondolataimat is.

Kornai János meggyőző érveléssel bizonyítja, hogy az innovatív társadalom létrejöttének elsődleges feltétele a piaci mechanizmusok térnyerése. Az empirikus adatok azonban azt is mutatják, hogy igazán akkor gyorsul fel az innováció, ha ehhez aktív állami szerepvállalás is társul. A Kornai [2011] 1. táblázatában felsorolt 89 innováció valóban kizárólag kapitalista országból származik, de az is szembetűnő, hogy ezek nagy része éppen az Egyesült Államokban jött létre, abban az országban, amely a legtöbbet költötte fegyverkezésre és ürkutatásra a vizsgált időszakban (1917-től napjainkig), tehát a kutatások jelentős részét az állam kezdeményezte és támogatta. Számos empirikus tanulmány alátámasztja, hogy a fejlett országok esetében az állam által finanszírozott hadikiadások pozitív hatással vannak az innovációra és a növekedésre (Alptekin-Levine [2012]). Az izraeli innovációs sikerekben is jelentős szerepet játszott a hadiipar (Haour [2005]).

Másrészről azonban - véleményem szerint - Stiglitz és Greenwald túlzásba esik az állami beavatkozások hatáskörét és kívánatos méretét illetően. A modellek alapján rendre arra jutnak, hogy az államnak érdemes korlátoznia az áruk, a tőke és a munkaerő (!) szabad áramlását, sőt egyik modelljükből egyenesen az következik, hogy a teljes autarkia az optimális a tanuló társadalom szempontjából. Ez az irreális eredmény annak köszönhető, hogy nagyon speciális és nagyon szűk tanulásfogalmat használnak: a termelés közbeni tanulást, amelynek értelmében a tanulás kizárólag a termelés méretétől függ. Ezzel egyrészt alulértékelik a formális tanulás és így az egész oktatási rendszer jelentőségét. Pedig az általuk 
számos alkalommal pozitív példaként emlegetett Dél-Korea nemcsak arról nevezetes, hogy az állam nemzetközi összehasonlításban is jelentős szerepet vállal a gazdaságélénkítésben, hanem arról is, hogy a világon itt a legmagasabb a felsőoktatásban való részvétel. Másrészt a termelés közbeni tanulás fogalma eleve egyfajta bezárkózást sugall, pedig a valóságban a tanulást legalább annyira inspirálja a kultúrák találkozása, az emberi kapcsolatok és a kommunikáció, mint az autodidakta kísérletezés és a hibák korrigálása. Erre utal Kenneth Arrow-nak a könyvben szereplő kommentárja is:

„A kereskedelem egyik elönye, hogy elösegíti a technológiai tudással kapcsolatos információk elterjedését. A kapcsolat megléte - az ideák áramlása - tovagyürüző hatásokhoz, tanuláshoz és erősebb versenyhez vezet." (Arrow [2014] 507. o.)

Mindezek alapján nehéz elfogadni azt az érvelést, hogy az áruk, a tőke és a munkaerő szabad áramlása akadályozza a tanulást. Solow másfajta kétséget is megfogalmaz a kereskedelmi korlátozásokkal szemben:

„....meglehetös önmérsékletet igényelne a világ többi országától, hogy elfogadják a fejlődő országok átfogó vámvédelmét, miközben ezek az országok továbbra is szabadon exportálhatnának. Azt el tudom képzelni, hogy a világ elfogadja egyik vagy másik iparág védelmét, de az egész fiatal gazdaság védelmét nem lenne könnyủ eladni." (Solow [2014] 500-501. o.)

Ugyanígy az sem valósítható meg, hogy egyszerre sok ország tartósan gyengén tartsa a saját devizáját.

Arrow kommentárjában kiemeli, hogy az innovációkkal kapcsolatos egyik legnagyobb rejtély az, hogy miért nem képes a vállalatok többsége tartósan felzárkózni az iparági legjobb gyakorlathoz (best practice), más szóval, miért nem terjed megfelelő mértékben a tudás. Úgy látja, hogy ez lényeges kérdés, amelyre Stiglitz és Greenwald nem ad választ, és reméli, hogy további kutatások majd fényt derítenek e széleskörüen dokumentált jelenség okaira.

Solow is hozzászólt ehhez a kérdéshez: egy McKinsey-kutatásra hivatkozott, amelyben empirikusan azt vizsgálták, mi magyarázza az egyes országokon belüli termelékenységeltéréseket. A McKinsey-jelentés megállapította, hogy a lemaradások lényegében menedzsmentbeli hiányosságokra vezethetők vissza, amelyek hátterében szinte kivétel nélkül valamiféle formális vagy informális állami védelem/ támogatás állt. És ez nemcsak az Egyesült Államokra, de a fejlődő országokra (Brazília, Oroszország és India) is igaznak bizonyult. Ez alapján Solow megfogalmazta azon aggodalmát, hogy az állami támogatás növeli annak erkölcsi kockázatát, hogy a menedzserek a védelem hatására elkényelmesednek, és versenyzés helyett a járadékvadászatot és a lógást választják, ami összecseng Kornai Jánosnak a puha költségvetési korlátról szóló elméletével is. Megjegyzem, hogy Berlinger és szerzötársai [2015] az állami támogatás és az erkölcsi kockázat kapcsolatát vizsgálta, és egy szerződéselméleti modell alapján arra jutott, hogy optimális támogatási szerződés esetén az állami támogatás nem elrontja, hanem javítja az ösztönzöket, így nem növeli, hanem csökkenti az erkölcsi kockázatot. Az állami támogatásnak a gyakorlatban 
tapasztalható teljesítményromboló hatása tehát nem logikai törvényszerűség, sokkal inkább a megvalósítással összefüggő gyakorlati probléma. ${ }^{10}$

A Stiglitz-Greenwald-könyv egyik legérdekesebb része a szabadalmi rendszerekröl szóló elemzés. A szerzőpáros nagyon meggyőzően mutatja be a szabadalmak megannyi negatív hatását, különösen a túl erős szellemi tulajdonjogok által gerjesztett, torz ösztönzőket. Mégis, véleményünk szerint, a sok negatívum ellenére valószínűleg nincs ennél jobb módszer az innovációösztönzésre. ${ }^{11}$ A pályadíjakat csak olyan esetben lehet használni, amikor pontosan tudjuk, hogy mi az innováció célja. Az állami kutatási támogatások föként az alapkutatásokban játszhatnak szerepet. A nyílt forráskód mozgalma pedig spontán szerveződés, amely nehezen irányítható. Amikor pedig a szerzők azt javasolják, hogy a szabályozásban nagyobb súlyt kell adni a közérdeknek a magánérdekkel szemben, akkor az egyúttal nagyobb teret enged a központi hatalomnak az egyénnel szemben, ami veszélyes folyamatokat indíthat el, hiszen a diktatúrák is a közérdekre való hivatkozással korlátozzák a magántulajdont és az egyéni szabadságjogokat.

Philippe Aghion hozzászólásának legfontosabb gondolata az, hogy a StiglitzGreenwald-modellek kizárólag egy pozitív externáliára, a tanulásra koncentrálnak, miközben figyelmen kívül hagyják a termelés másik, vitathatatlanul jelen lévő, ám ellenkező előjelü externáliáját, a környezetrombolást, amely maga után vonja a kimerülő erőforrások áremelkedését, az élhető környezet és emiatt az emberek általános egészségi állapotának leromlását, illetve a katasztrófakockázat növekedését (Aghion [2014]).

Ha ezt a negatív hatást is beépítjük a modellekbe, akkor az aktuális helyzettől függően a termelésfokozó állami politika akár káros is lehet. ${ }^{12}$ Ezzel a kiegészítéssel egyébként komplexebbé válnának a modellek - nemcsak azért, mert a két externális hatás ellentétes irányú, hanem azért is, mert nem függetlenek egymástól. A lehetséges kölcsönhatásokat az 1. ábra szemlélteti.

Stiglitz-Greenwald [2014] csak a termelés és az innováció közötti pozitív visszacsatolással foglalkozott (lásd vastag, folytonos hurok), vagyis azzal a multiplikatív, öngerjesztő folyamattal, hogy a termelés növeli a tudást, a tudás pedig növeli a termelést. Nem meglepő, hogy modelljeikben rendszerint azt az eredményt kapták, hogy a termelés jelenbeli állami támogatása hosszabb távon óriási hasznot hoz a társadalom számára.

Ha azonban bekapcsoljuk a környezeti változót is, akkor a termelés növelése rombolja a környezetet, ugyanakkor a leromló környezet visszafogja a termelést, ami összességében negatív visszacsatolást visz a rendszerbe (lásd legfelső vékony folytonos nyíl). Ez a negatív visszacsatolás természeténél fogva egyfajta kiegyensúlyozást jelent, hiszen így már nem feltétlenül érdemes a végtelenségig fokozni a termelést.

${ }^{10}$ A valóságban semmi garancia sincs arra, hogy a politikusok és bürokraták által működtetett állam optimális szerződéseket kössön, mert ehhez az kellene, hogy tökéletesen pártatlan, bölcs és önzetlen legyen.

${ }^{11}$ Mint ahogy a demokráciánál sincs jobb politikai berendezkedés, hiába igaz rá, hogy sérülékeny, esetleges, manipulálható, költséges stb.

${ }^{12}$ Azért is meglepő ennek a hatásnak a figyelmen kívül hagyása Stiglitz-Greenwald [2014]-ben, mert Stiglitz tagja volt a francia kormány által felkért, a GDP-növekedés mint sikermutató helyettesítésén dolgozó bizottságnak (Commission on the Measurement of Economic Performance and Social Progress), amelynek 2009-es jelentésében a környezeti hatások komoly hangsúlyt kaptak. 
1. ábra

A termelés, az innováció és a környezet lehetséges kölcsönhatása

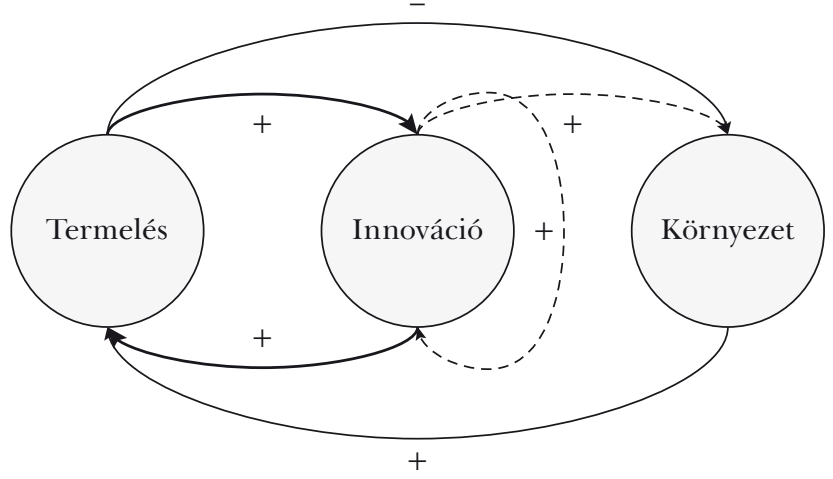

Forrás: saját szerkesztés.

Ráadásul a valóságban a folytonos nyilak mellett érvényesülhetnek a szaggatott nyilakkal jelzett hatások is. Például a technológiai fejlődés fokozza a tanulási képességet, egyúttal a tiszta technológiák térnyerésével csökkenti a környezetrombolást. Vegyük észre, hogy ha a szaggatott nyilakkal jelölt hatásokat nem vennénk figyelembe (azaz függetlennek tekintenénk a technológiai fejlődést és a környezet állapotát), akkor hosszú távon a tanulás környezeti katasztrófához vezetne.

$\mathrm{Az}$ is világos, hogy ha ezek a pozitív és negatív externáliák közel azonos mértéküek, akkor lehetséges, hogy nagyjából kioltják egymást, és így a szabad piaci egyensúly egészen közel van a társadalmi optimumhoz. Természetesen a valóságban semmi nem biztosítja, hogy a két hatás éppen kioltja egymást. Ezért a helyes gazdaságpolitikai ajánlás nem lehet sem az, hogy az állam minden erővel fokozza a termelést, sem az, hogy magára kell hagyni a piacot, hanem inkább az, hogy a szakpolitikát minden (!) fontos externália és egyéb piaci vagy állami kudarc figyelembevételével kell megtervezni. ${ }^{13}$

Speciálisan Acemoglu és szerzőtársai [2006] dolgozta ki az úgynevezett irányított technológiaváltás (directed technical change) modelljét, amely tartalmazza az 1. ábrán szereplő kapcsolatokat, de annál sokkal összetettebb és részletgazdagabb. E modellben a szerzők meghatározták az optimális állami politikát, és ebben kiemelkedő szerepe van a „tiszta” technológiák kutatási (!) támogatásának (a „tiszta” termelés támogatása vagy a szennyezés megadóztatása jóval kevésbé hatékony eszköz). Emögött az a gondolatmenet húzódik meg, hogy amíg a piacon a szennyező technológia a domináns, addig a kutatások a szennyező technológia fejlesztésére irányulnak, és a piaci mechanizmusok gátolják a „tiszta” technológiák elterjedését, ami veszélyezteti a fenntarthatóságot. Az állami beavatkozásra

\footnotetext{
${ }^{13}$ További piaci kudarcot okozhat az aszimmetrikus információ, a növekvő mérethozadék, a közjószág stb. A kormányzati/állami kudarcok között szokták említeni a kiszorítási hatást, a szabályozási arbitrázsokat, a szabályozó foglyul ejtését, a járadékvadászatot és a politikai korrupciót.
} 
azért van szükség, hogy a „tiszta szektor” elérhesse azt a kritikus tömeget, amely már versenyképessé teszi a kutatást és a termelést ezen a területen. Ha ez sikerül, akkor a kutatók és termelök önérdeküktől vezérelve átnyergelnek az immár kifizetődő „tiszta” technológiára, és innentől fogva a piaci folyamatok is a fenntarthatóság irányába hatnak. Ha tehát az állam időben és megfelelö módon avatkozik be, akkor elkerülhető a környezeti katasztrófa, közben növelhető a termelés (és így az életszínvonal is), sőt egy idő után megszüntethető az állami támogatás, mert annak szerepét a piaci mechanizmusok veszik át. ${ }^{14}$

Az irányított technológiaváltás modellje tehát kiváló példa arra, hogy a piacnak és az államnak nem egymás ellenében, hanem egymással összhangban kell müködnie. Nyilvánvaló, hogy ebben Kornai és Stiglitz is tökéletesen egyetért:

- Kornai János szerint: „[A] gazdaságpolitika döntéshozóinak el kellene kerülniük mindkétfajta hibát; túl messzire menni a deregulációval, vagy túl sok (és/vagy rosszul célzott) szabályt bevezetni." (Kornai [2011] 58. o.)

- A Stiglitz-Greenwald szerzőpáros szerint: „... a piacot és az államot egymás kiegészítőjeként kell kezelnünk, amelyek együttműködnek. Nem a piac vagy az állam között kell választanunk, hanem olyan gazdasági rendszert kell kialakítanunk, amelyben e kettő konstruktívan együttmüködik.” (Stiglitz-Greenwald [2014] 479. o.)

\section{2. ábra}

Nemlineáris kapcsolat az állami beavatkozás és a társadalmi jólét között

Össztársadalmi jólét

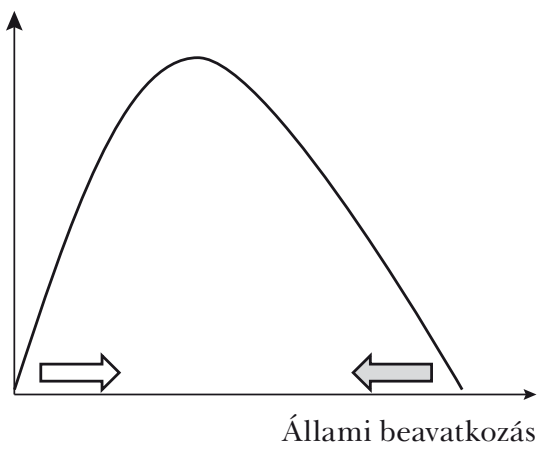

Forrás: saját szerkesztés.
Ez alapján érdemes tartózkodni az olyan általánosító kijelentésektől, hogy több piaccal vagy több állami beavatkozással minden probléma megoldható. Különösen súlyos csúsztatás, ha valaki eközben Kornaira vagy Stiglitzre hivatkozik. A közgazdasági problémák általában úgy formalizálhatók, hogy egy konvex halmazon keressük az optimumot, amely többnyire nem a halmaz szélén, hanem a halmaz belsejében található, más szóval, a bonyolult kérdésekre adott végletesen egyszerü válaszok általában rosszak. A végletes megoldások iránti vonzódás hátterében gyakran az áll, hogy lineáris (sőt egyenesen arányos) összefüggést feltételezünk ott is, ahol erről szó sincs. ${ }^{15}$ A 2. ábra illusztrálja, hogy milyen alakú lehet a valóságban a kapcsolat a nehezen definiálható és főleg nehezen számszerüsíthető „össztársadalmi jólét" és az állami beavatkozás mértéke között.

A 2. ábra szerint tehát ahhoz, hogy felüljünk a ló hátára, elöször is be kell azonosítanunk, hogy melyik oldalán vagyunk éppen, és vigyáznunk kell, nehogy túlzott lelkesedésből átessünk a másik oldalára. Az ábra persze több szempontból is leegyszerüsítő,

${ }^{14}$ A Stiglitz-Greenwald [2014] könyv végén szerepel Philippe Aghion hozzászólása a vitához, aki felhívja a figyelmet Acemoglu és szerzőtársai [2006] eredményeire; a kötetben ő maga is szerzőtársként müködött közre (Aghion [2014]).

${ }^{15}$ Számos érdekes közgazdasági és hétköznapi példát mutat erre Ellenberg [2016]. 
de az biztonsággal állítható, hogy az összefüggés nem lineáris, hanem inkább fordított $U$ alakú, azaz a társadalmi optimum valahol a két véglet között található. Láttuk, hogy ebben Kornai és Stiglitz is egyetért, de feltételezhetően mást gondolnak az össztársadalmi jólét és az állami beavatkozás tartalmáról, valamint a görbe alakjáról, így magáról az optimumhelyről is. És ha még mindezekben egyet is értenének, akkor is munkáikban a görbe más-más szakaszával foglalkoznak: Kornai a jobb oldali csökkenő szakasszal (szürke nyíl), míg Stiglitz a bal oldali emelkedő szakasszal (fehér nyíl), és így nézeteik nem ellentétesek, hanem inkább kiegészítik egymást. Az pedig már ennek a két kiváló könyvnek az összehasonlításából is látszik, hogy mindketten nagymértékben hozzájárultak a piac és az innováció közötti kapcsolat megértéséhez, és gondolataikkal - igazi innovátorként - számos további kutatást inspirálnak.

\section{Hivatkozások}

Acemoglu, D.-Aghion, P.-Bursztyn, L.-Hemous, D. [2006]: The Environment and Directed Technical Change. American Economic Review, Vol. 102. No. 1. 131-166. o. https://doi. org/10.2139/ssrn.1668575.

Aghion, P. [2014]: Commentary: The Case for Industrial Policy. Megjelent: Stiglitz-Greenwald [2014] 20. fejezet, 492-498. o.

Alptekin, A.-Levine, P. [2012]: Military Expenditure and Economic Growth: A MetaAnalysis. European Journal of Political Economy, Vol. 28. No. 4. 636-650. o. https://doi. org/10.1016/j.ejpoleco.2012.07.002.

ARROW, K. J. [1979/1962]: A termeléssel szerzett tudás jelentősége a gazdasági elmélet számára. Megjelent: Arrow. K. J.: Egyensúly és döntés. Válogatott tanulmányok. Közgazdasági és Jogi Könyvkiadó, Budapest, 299-319. o.

Arrow, K. J. [2014]: Commentary. Megjelent: Stiglitz-Greenwald [2014] 22. fejezet, 504-508. o. Arrow, K. J.-Debreu, F. [1979/1954]: Az egyensúly létezése versenygazdaságban. Megjelent: Arrow. K. J.: Egyensúly és döntés. Válogatott tanulmányok. Közgazdasági és Jogi Könyvkiadó, Budapest, 21-47. o.

Berlinger Edina-Juhász Péter-Lovas Anita [2015]: Az állami támogatás hatása a projektfinanszírozásra erkölcsi kockázat és pozitív externáliák mellett. Közgazdasági Szemle, 62. évf. 2. sz. 139-171. o.

EllenberG, J. [2016]: Hogy ne tévedjünk. A mindennapi élet rejtett matematikája. Park Könyvkiadó, Budapest.

HAOUR, G. [2005]: Israel, a Powerhouse for Networked Entrepreneurship. International Journal of Enterpreneurship and Innovation Management, Vol. 5. No. 1-2.39-48. o. https:// doi.org/10.1504/ijeim.2005.006336.

KiRÁLY JÚlIA-GÁL RóBERT IVÁN [2016]: Simonovits 70. Társadalom- és természettudományi írások. Arkhimédésztől az időskori jövedelmekig. MTA KRTK Közgazdaság-tudományi Intézet, Budapest.

KoRNAI JÁNOs [2011]: Gondolatok a kapitalizmusról. Kölcsönhatás a rendszerek és a technikai haladás között. Akadémiai Kiadó, Budapest.

Kornai JÁNos [2016]: Még egyszer a „rendszerparadigmáról”. Tisztázás és kiegészítések a posztszocialista régió tapasztalatainak fényében. Közgazdasági Szemle, Vol. 63. No. 10. 1074-1119. o. https://doi.org/10.18414/ksz.2016.10.1074. 
SChumpeter, J. A. [1980/1912]: A gazdasági fejlődés elmélete. Vizsgálódás a vállalkozói profitról, a tőkéről, a hitelről, a kamatról és a konjunktúraciklusokról. Közgazdasági és Jogi Könyvkiadó, Budapest.

Solow, R. M. [1957]: Technical Change and the Aggregate Production Function. Review of Economics and Statistics, Vol. 39. No. 3. 312-320. o. https://doi.org/10.2307/1926047.

Solow, R. M. [2014]: Commentary. Megjelent: Stiglitz-Greenwald [2014] 21. fejezet, 499-503. o. Stiglitz, J. E-Greenwald, B. C. [2014]: Creating a Learning Society: A New Approach to Growth Development and Social Progress. Columbia University, New York. Magyarul: A tanuló társadalom megteremtése. Napvilág Kiadó, Budapest. 